\title{
A social identity complexity theory reading of Philemon
}

\begin{tabular}{|c|c|}
\hline \multicolumn{2}{|c|}{$\begin{array}{l}\text { Author: } \\
\text { Jacobus Kok }{ }^{1,2} \text { (D) } \\
\text { Ilse Swart }^{1,2} \text { (D) }\end{array}$} \\
\hline \multicolumn{2}{|c|}{$\begin{array}{l}\text { Affiliations: } \\
{ }^{1} \text { Department of New } \\
\text { Testament, Evangelische } \\
\text { Theologische Faculteit, } \\
\text { Leuven, Belgium }\end{array}$} \\
\hline \multicolumn{2}{|c|}{$\begin{array}{l}{ }^{2} \text { Department of New } \\
\text { Testament and Related } \\
\text { Literature, Faculty of } \\
\text { Theology and Religion, } \\
\text { University of Pretoria, } \\
\text { Pretoria, South Africa }\end{array}$} \\
\hline $\begin{array}{l}\text { Research Proj } \\
\text { Project Leade } \\
\text { Project Numb }\end{array}$ & $\begin{array}{l}\text { ect Registration: } \\
\text { r: J. Kok (I) } \\
\text { er: } 2615738\end{array}$ \\
\hline \multicolumn{2}{|c|}{$\begin{array}{l}\text { Description: } \\
\text { Ilse Swart is participating in } \\
\text { the research project 'Mission } \\
\text { and Ethics' directed by Prof. } \\
\text { Dr Jacobus Kok, Department } \\
\text { of New Testament and } \\
\text { Related Literature, Faculty of } \\
\text { Theology and Religion, } \\
\text { University of Pretoria }\end{array}$} \\
\hline $\begin{array}{l}\text { Correspondin } \\
\text { Jacobus Kok, } \\
\text { kobus.kok@et }\end{array}$ & $\begin{array}{l}\text { g author: } \\
\text { f.edu }\end{array}$ \\
\hline \multicolumn{2}{|c|}{$\begin{array}{l}\text { Received: } 15 \text { Mar. } 2021 \\
\text { Accepted: } 24 \text { May } 2021 \\
\text { Published: } 30 \text { July } 2021\end{array}$} \\
\hline \multicolumn{2}{|c|}{$\begin{array}{l}\text { How to cite this article: } \\
\text { Kok, J. \& Swart, I., 2021, 'A } \\
\text { social identity complexity } \\
\text { theory reading of Philemon', } \\
\text { HTS Teologiese Studies/ } \\
\text { Theological Studies 77(4), } \\
\text { a6621. https://doi.org/ } \\
\text { 10.4102/hts.v77i4.6621 }\end{array}$} \\
\hline \multicolumn{2}{|c|}{$\begin{array}{l}\text { Copyright: } \\
\text { (C) 2021. The Authors. } \\
\text { Licensee: AOSIS. This work } \\
\text { is licensed under the } \\
\text { Creative Commons } \\
\text { Attribution License. }\end{array}$} \\
\hline \multirow[b]{2}{*}{$\begin{array}{l}\text { Read online: } \\
\text { 口ifor }\end{array}$} & \\
\hline & $\begin{array}{l}\text { Scan this QR } \\
\text { code with your } \\
\text { smart phone or } \\
\text { mobile device } \\
\text { to read online. }\end{array}$ \\
\hline
\end{tabular}

This article provides new perspectives on navigating complex social identity in the letter to Philemon by means of the heuristic use of social identity complexity theory (SICT) in combination with socio-rhetorical analysis (SRA). The application of SICT as a heuristic tool in New Testament (NT) studies is relatively new, but it is positioned within the novel research being carried out on social identity theory in the NT.

Contribution: This article wants to make a new contribution by illustrating how SICT can help us to think in more nuanced ways about nested identity(s) in Philemon.

Keywords: social identity complexity theory; social identity theory; Philemon; Paul; Onesimus; slave; slavery; identity.

\section{Introduction}

Most recently, the T\&T Clark Social Identity Commentary (Tucker \& Kuecker 2020) appeared, which followed on the T\&T Clark Handbook to Social Identity in the New Testament (NT) (Tucker \& Baker 2014). Although the reality of the occurrence of 'intersectional' and 'cross-cutting' identities are recognised in these works (e.g. Hunt 2020:533), none of them make use of the some of the latest insights in social identity research, for example the social identity complexity theory (SICT) developed by Roccas and Brewer (2002) and first applied by Kok (2014) to the NT. ${ }^{1}$ In previous studies, it has inter alia been argued that manumission is not the main objective of the letter, but rather the shift in the relationship between master and slave towards brothers and the call to reconciliation. ${ }^{2}$ The apparent conflict between the identity of slave and brother has not gone unnoticed in previous research. ${ }^{3}$ This article aims to explore the social identity complexity of Onesimus in the letter to Philemon concerning his intersectional and cross-cutting identity as both a slave and 'beloved brother' in Christ. ${ }^{4}$ Furthermore, insights from socio-rhetorical analysis (SRA) will aid us to see how the author of Philemon rhetorically wanted to shape the readers' identity within the ancient Mediterranean group-oriented world. ${ }^{5}$

\section{Methodology}

Although different models from Social Identity Theory (SIT) have recently been used to look at both the slave and brother identity of Onesimus, they have left some gaps that SICT can fill (Tucker 2014:407-424). Firstly, the dual-identity model as applied by Brian Tucker merely looks at conflict resolution on the level of the group. Social identity complexity theory enables us to connect the cognitive representation of the individual to the relation between perceived in- and outgroups. Secondly, the self-categorisation theory and cognitive ordering theory that Roitto (2008:141) utilised to look at Onesimus could be enhanced further by insights from SICT to map the interrelation between the ingroups of Onesimus' identity perception within his social context. SIT as used in the past accounts only partly for the multiplicity of identities, but lacks the ability to demonstrate the relation between the multiple ingroup memberships. Thus, to gain insight into

\section{For dual identity, see Haslam (2004:128)}

2.De Vos (2001:91-93, 105), Wright (2008) and McKnight (2017:1, 5, 26-29) argue that the crux of PHLM is not manumission, but instead it is related to reconciliation.

3.Examples include Petersen (2008:93-123), who mainly looks at the different roles of Onesimus, Philemon and Paul in terms of the early church structure. He argues that the roles, as presented in PHLM, point to an early form of institutionalisation of the Christ-following community. Petersen does reflect on this sociologically and does not apply any social identity theories; See Tucker (2014:407-424) and also Roitto (2008) for a social identity approach.

4.From here on we will refer to the letter of Philemon with PHLM, whereas the person Philemon will remain Philemon.

5.See Robbins (1996) for the importance of socio-rhetorical interpretation.

Note: Special Collection: From timely exegesis to contemporary ecclesiology: Relevant hermeneutics and provocative embodiment of faith in a Corona-defined world - Festschrift for Stephan Joubert, sub-edited by Willem Oliver (University of South Africa). 
how Paul maintains or transforms the boundaries of social identity, a method is required that does not merely acknowledge multiple identities, but one that charts the relation between the individual and her ingroups. In this article it will be argued that insights gained from SICT in NT studies may aid in our understanding of the larger Christfollowing community behind the NT.

The application of social-scientific models offers NT studies heuristic tools that uncover new layers of understanding of the text. However, such models must not be forced onto the text, but make explicit which is implicit in the texts and its social background (Clarke \& Tucker 2014:49-51). Tucker (2010:75) correctly argues that 'understanding social identity evident in a text should be anchored in the historical situation of the recipients $[\ldots]^{\prime}$. Furthermore, SRA analyses the social function of texts, viewing it as a tapestry of different but related interwoven textures demanding of us to consider the social background and dynamics behind these texts (Robbins 1996:3).

Within SRA there are multiple textures through which the different social realities of a text can be examined. For the purpose of this article the social and cultural texture of SRA will be considered. This texture seeks to discern the voices of both the author and characters appearing within the text. Moreover, this texture assumes that the characters in the text represent the lived experience of those behind the text. In other words, the text operates as a mirror to its context, precisely because the text is a product of [or: is embedded in] its context (Robbins 1996:34).

Through the lens of this texture, the language used in PHLM forms indicators of particular social realities and, therefore, the social and cultural texture is essential to gain insight into the identity perception of Onesimus in relation to his social context.

Robbins distinguishes eight different topics within the social and cultural texture of SRA. Considering that this article examines the identity and ingroup dynamics of the world behind PHLM, we apply the honour, guilt and rights culture and dyadic and individualistic personalities topics. Once, with the help of these topics, the social realities behind the text are explained, one starts to see how the content relates to the dominant culture behind the text. Therefore, we argue that extracting these topics is essential to discern whether Paul maintains or transforms social boundaries through the text of PHLM.

\section{Social identity complexity theory}

Social identity complexity theory emerged from both multiple categorisation and social cognition theories and was developed by Roccas and Brewer (2002). The relation between multiple ingroup memberships within the individual had been somewhat neglected up to then. Roccas and Brewer aimed to provide a model that could illustrate multiple categorisation by examining the subjective representation of the individual in relation to her multiple identities. Social identity complexity theory's models are designed to chart the often complex and unsolidified interrelation of ingroup memberships within the individual. Moreover, in charting the complexity of the individual's ingroup representations it also uncovers one's evaluation of the outgroup. Social identity complexity theory proposes that identity complexity occurs when there is a lack of overlap between the individual's multiple identities, whereas an understanding of one's complexity results in an increased level of inclusivity towards outgroups. Kok (2014:2) argues that this is because 'they [individuals that acknowledge identity complexity] have the ability to deal with complexity in their own social identity and tend to be more understanding of the outgroups'.

The four models of SICT illustrate how one may assess the relation between the different ingroup memberships.

\section{Intersection}

The point of overlap or intersection (green) between multiple identities becomes the way one sees himself or herself. (See Figure 1.) Thus, despite the variety of ingroup memberships, the individual upholds one single ingroup representation. Because the place of convergence forms one identity resulting in one strong ingroup, those who do not identify with this strong identity belong to the outgroup.

\section{Dominance}

The way in which one of the identities (yellow) may dominate other group identities (green) is called dominance. (See Figure 2.) Within this model, all identities (y, $\mathrm{z}$, etc. [small letters indicating subordination to $\mathrm{X}]$ ) that are not dominant are considered subordinate in relation to one's dominant $(X)$ identity. In the picture $\mathrm{y}, \mathrm{z}$ is divided by $\mathrm{X}$ to make the metaphorical point that $\mathrm{X}$ is dominant in that it influences its dominance over $y, z$, etc. Therefore, the dominant identity is

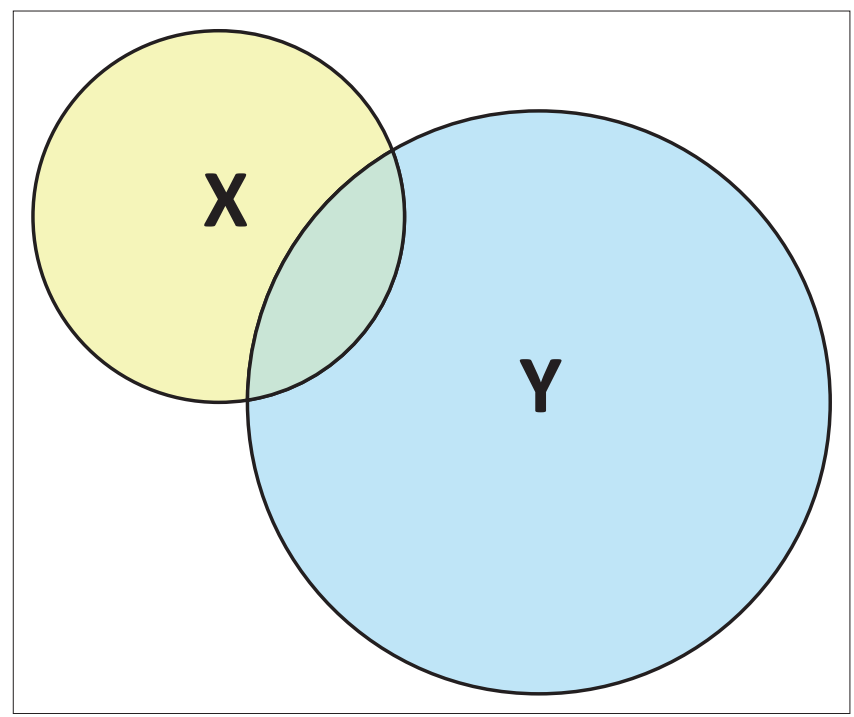

Source: Model adapted from Roccas, S. \& Brewer, M.B., 2002, 'Social identity complexity', Personality and Social Psychology Review 6(2), 88-106. https://doi.org/10.1207/ S15327957PSPR0602_01

FIGURE 1: Intersection. 


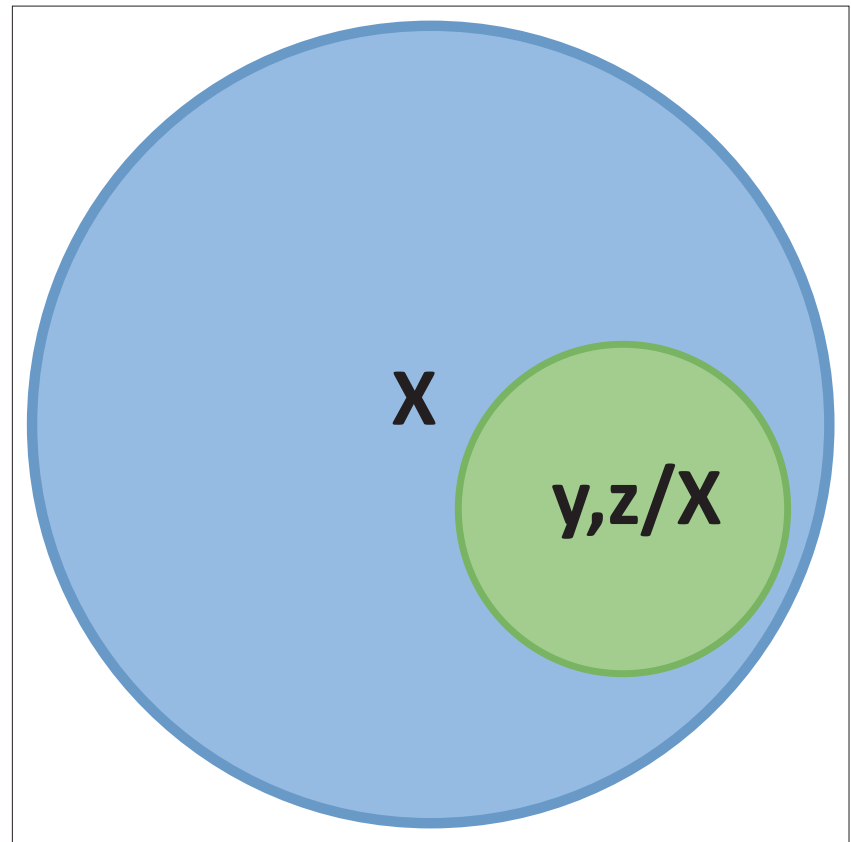

Source: Model adapted from Roccas, S. \& Brewer, M.B., 2002, 'Social identity complexity', Personality and Social Psychology Review 6(2), 88-106. https://doi.org/10.1207/ S15327957PSPR0602_01

FIGURE 2: Dominance.

the major identifier of the individual. Moreover, all people who uphold a similar dominant identity are considered to belong to the ingroup, whereas those who maintain a different dominant identity are part of the outgroup.

\section{Compartmentalisation}

In contrast to the models of intersection and dominance, within compartmentalisation it is not the overlap or relation between the identities that determine the identity one identifies with but rather the context in which one's identity is expressed. (See Figure 3.) The context-based identification process results in the differentiation and isolation of the individual's multiple identities (some might be more dominant than others). As a result of the absence of convergence between multiple identities, the inclusivity towards outgroup members is low in this model.

\section{Merger}

In the merger model, there is neither convergence nor contextbased identification with one's ingroups. (See Figure 4.) Instead, all identities are embraced simultaneously and can coexist. As a result, the model of merger has great inclusivity and 'transcends single categorical divisions between people' (Roccas \& Brewer 2002:4). There are no strong ingroup boundaries as all who recognise at least one identity are part of the ingroup.

\section{Socio-rhetorical analysis}

As mentioned here, before SICT can shed light on the conservation or transformation of identity in PHLM, we must first consider the socio-cultural dynamics behind the texts, specifically honour, shame and dyadic personalities.

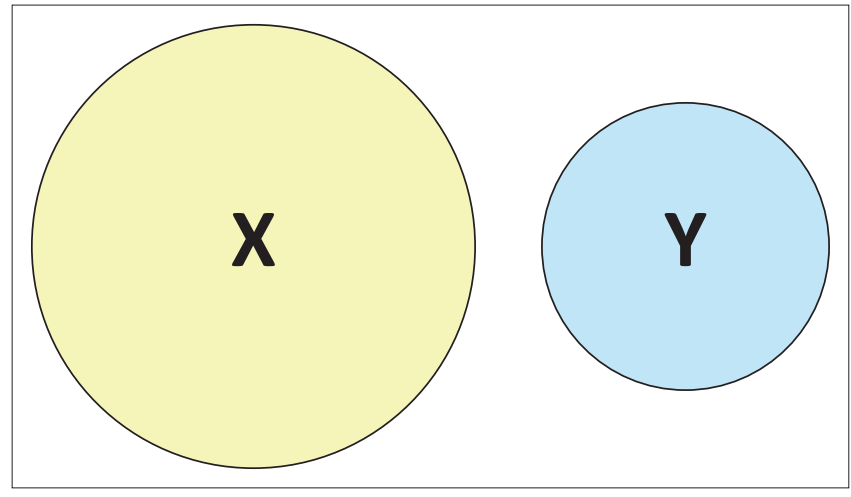

Source: Model adapted from Roccas, S. \& Brewer, M.B., 2002, 'Social identity complexity', Personality and Social Psychology Review 6(2), 88-106. https://doi.org/10.1207/ S15327957PSPR0602_01

FIGURE 3: Compartmentalisation.

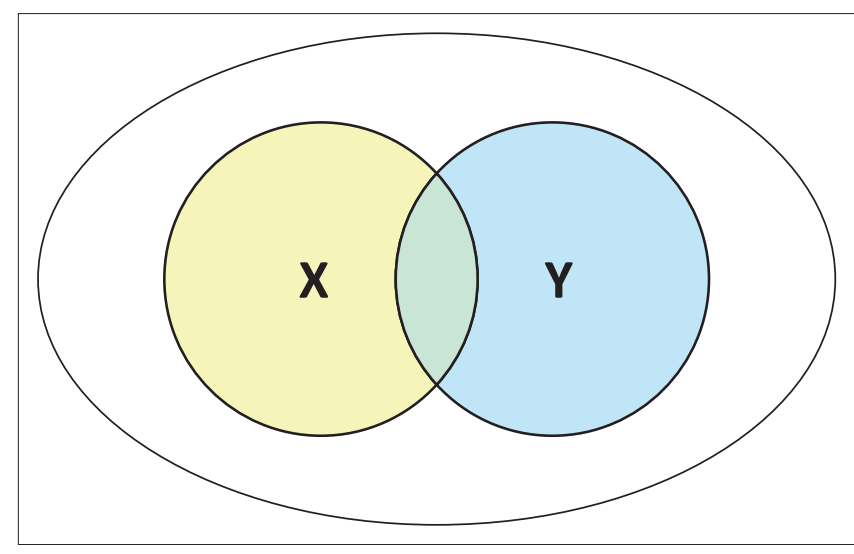

Source: Model adapted from Roccas, S. \& Brewer, M.B., 2002, 'Social identity complexity', Personality and Social Psychology Review 6(2), 88-106. https://doi.org/10.1207/ S15327957PSPR0602 01

FIGURE 4: Merger.

\section{Honour and shame culture}

The foundation for the first-century Graeco-Roman world is the value of honour and shame. It is one of the primary means through which identity, ingroup behaviour and relations between them in the ancient world are to be understood. To inhabit one's rightful place in society a person has to conform to the honour and shame expectations in accordance with one's social position. Honour is the highest goal and is attained through following a set of social rules in ancient Mediterranean culture. One's place in society and the household determine how honour is ascribed to a person. In fact, one might say that a person's social identity determines what type of behaviour is considered to be honourable. ${ }^{6}$

On the opposite end of this value is shame. Moreover, shame in the ancient Graeco-Roman world belongs to the feminine area of life and relates to 'weakness, cowardice and lack of generosity' (Pilch \& Malina 2016:19). However, shame can also be positive when shameful behaviour corresponds to one's social position and, thus, fits one's role expectation. Therefore, a slave has positive shame when she behaves according to her social role and is shameless when she does

6.Pilch and Malina (2016:89). Because Robbins (1996) heavily relies on Malina for the explanation of the social and cultural topics, we will also use Malina's work to increase our understanding of these topics. 
not. One can thus also lose positive shame by violating social rules and expectations resulting in shamelessness, which often implied marginalisation and exclusion. Therefore, even within shame there is honour, as long as one's shame corresponds to one's role expectation (Pilch \& Malina 2016:90).

A crucial element of honour and shame includes the mechanisms through which honour or shame is achieved. Especially in the light of PHLM research, this cannot be overlooked. Gaining honour or shame consists of a passive and active aspect. Firstly, honour or shame can be passive, which is the honour or shame ascribed to someone by birth. For example, the family into which one is born determines largely one's honour or shame. Secondly, we speak of active honour and shame when external voices ascribe honour or shame to an individual. For instance, one's honour can be lost if a particular social group rejects the individual's social position. Here, it is important to note that honour is gained when one's internal identity perception matches an external group's perception. In other words, one's place in society is assured when an internal reality meets the public's perception of the individual. As we will see later, the relation between the internal and external perception means that identity in the ancient world is largely dependent on group perception (Malina 2001:50).

The mechanism of this value cannot be overlooked in our interpretation of Onesimus' identity construction by Paul. It may lead to the conclusion that Onesimus' new identity is transformed regardless of the reaction to Paul's request by both Philemon and the Christ-following ingroup behind PHLM. N.T. Wright, for example, has argued that Onesimus does not depend on Philemon's response to Paul's request to receive or achieve his new status as a 'beloved brother' (Wright 2008:190-191). However, the perception of an individual's place and honour in society can only change under the approval of the public. In other words, it is not just crucial that Philemon confirms Onesimus' new identity, but without the endorsement of the whole ingroup Paul's request is in vain. Thus, it is arguable whether Wright is correct in stating that Onesimus' new identity is not dependent on Philemon's response because the approval of one's identity by the whole ingroup is required so as to attain honour. Therefore, if Paul is not persuasive enough and does not succeed to convince the whole ingroup behind PHLM, Onesimus will not gain a transformed identity within the community of faith. But if he is seen in a transformed manner as brother in Christ, based on Paul's view, this would have challenged Philemon and his Christ-following community.

Furthermore, against the background of PHLM we find two major themes in which this topic shapes social identity and expectation. The first theme concerns the household language of PHLM, and the second theme is that of kinship and brotherhood. Seeing these themes through the lens of the fundamental value of honour and shame will elucidate how

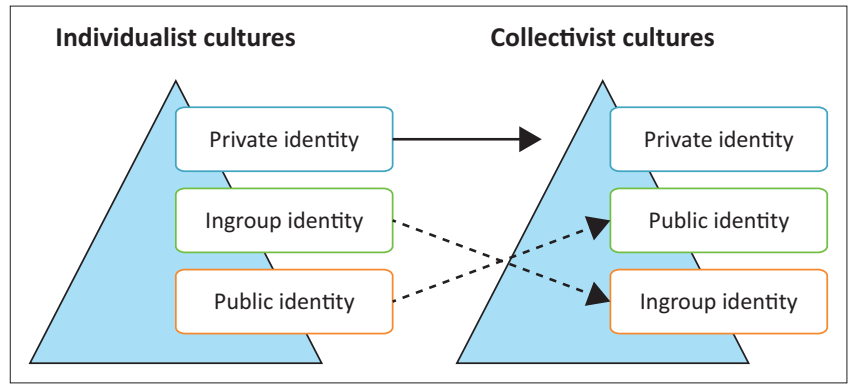

Source: Adapted from Malina, B.J. \& Pilch, J.J., 2006, Social-science commentary on the Letters of Paul, Fortress Press, Minneapolis, MN

FIGURE 5: Individualist and collectivist cultures.

Paul's request fits within its context. Moreover, uncovering this topic against the background of PHLM will help us see the nature of Onesimus' identity complexity as it uncovers the social dynamics at play.

\section{Household and ingroup identity}

Anthropologists differentiate between weak (contemporary individualist West) and strong group-oriented societies (ancient Mediterranean) (Malina \& Pilch 2006:344). The ancient dyadic or strong group-oriented person's (social) identity was mainly dependent on and determined by the groups that person belonged to. Thus, one's individual identity strongly correlated with the ingroup one belonged to. For a Westerner, one's ingroup-self as member of a family is not that important for self-identity and one's role therein does not determine one's self-definition in the public arena. The ancients thought the opposite. The group self-determined one's conception of personal self. Thus, what happens on the level of group-identity was much more significant then, as it is for us today. Schematically, it could be expressed as shown in Figure 5.

In the ancient world, one's position in the household determines one's place within the honour and shame spectrum. Philemon, as the master of Onesimus, would have been the head of the household, and therefore pater familias. Everything within the household falls under the authority (patria potestas) of the pater familias. Roman law dictates that the pater familias was the owner of the goods, livestock and persons of the household and therefore had legal authority (patria potestas) over all that belonged to the household, including slaves (White 2016:171-173). In other words, Philemon had full legal rights to do with Onesimus as he pleased because through the household code Onesimus would have been Philemon's rightful possession because the legal authority of the pater familias was not limited to the bounds of the physical household, even in the case that Onesimus was not Philemon's domestic slave, as his master Philemon would still have full authority over Onesimus (see MacDonald 2010:29-43, esp. 29-30).

Philemon's honour as head of the household is, as we have seen, largely dependent on the people around him. For example, his honourable status as pater familias would be in 
jeopardy if his peers would not ascribe him the honour that belongs to such a position. A disobedient and disrespectful slave, therefore, could threaten his honour from the perspective of the dyadic honour and shame culture of Paul's day.

For both Philemon and Onesimus to act according to the social code of their time, Onesimus would be expected to be obedient and submissive. On the contrary, Philemon would be expected to live up to the honourable expectations that his social role as pater familias requires of him. Thus, the most important value of their time would require both men to relate as superior to inferior, as master and slave. Yet, Paul's request contains language that suggests Philemon and Onesimus ought to assume a brotherly relationship.

\section{Brothers}

Instead of maintaining normative household codes, Paul strongly encourages Philemon to see Onesimus, his slave,

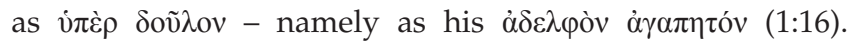
Therefore, through suggesting this change in perception, Paul challenges and transforms the ancient status quo in implying that a slave and master can now be brothers. The relation between brothers contains a notion of equality (Burke 2003:125-126), which is especially to be expressed in the context of the community of faith.

Paul writes that Philemon ought to receive Onesimus his slave as though he is his brother, even a beloved brother

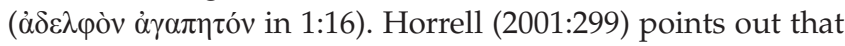
the Pauline notion of 'in-Christ' siblingship carries a relationship 'between equal siblings, who share a sense of affection, mutual responsibility and solidarity'.

Because of the bigger equality within the brotherly relationship, the fact that Paul asks that a master sees his slave as a brother is, at best, remarkable. Through altering Onesimus' identity perception, Paul provokes the traditional honour and shame code. The nature of their relationship shifts from the one-way honouring of a slave to his master, following cultural and social expectation, towards a mutual honouring as brothers in Christ.

Therefore, in the light of the ancient purpose of the brotherly relationship - being love, honour and unity ${ }^{8}$ - Paul's request to see the dynamic between slave and master transformed to such an extent that it is particularly challenging in an ancient social context.

In summary, the lens the honour and shame culture topic provides demonstrates how Paul challenges and alters the way in which honour and shame between these socially unequal persons ought to function in the light of Onesimus' new identity as brother in Christ. However, this also

7.Malina $(2001: 30-31)$ pointed out that ascribing honour is a safeguard for one's place in the public arena. Disrespect or dishonouring where honour is expected place in the public arena. Disrespect or dishonouring where honour is expected, would thus threaten this. He provides the example of the children in the household. When they obey their father, he is treated with honour if not they dishonour him and 'the father's peers would ridicule him, thereby acknowledging his lack of
honour as a father' (Malina 2001:31).

8.See Lim (2017:64-66) for a discussion on ancient sibling relations and mutual honour in the household. demonstrates the complexity of Paul's request. The honour and shame value and their role expectations prohibit Onesimus and Philemon to behave as though they were brothers. Yet, Paul does suggest just that. In order for Onesimus to experience a real change in his identity perception and reception, we must also consider the larger ingroup in which Onesimus is to be seen as a brother. Therefore, it is crucial that we move to another topic within SRA that looks at identity within one's social context, dyadic and individualistic personalities.

\section{Dyadic and individualistic personalities}

Because of the collectivist nature of ancient society, one's identity is always understood within the confines of ingroup belonging and outgroup rejection. Likewise, one's honour or shame is not merely understood individually but concerns the whole ingroup. Malina (2001:58-63) points out how the ancient person understood her identity through the eyes of others. Without the identity authentication of her ingroup, a person would not understand the self. The dyadic and individualistic personalities topic of SRA takes this reality into consideration in its analysis of texts. The topic looks at the text through the dyadic understanding of personality as determined by how one's social status and role are perceived by her social context (Robbins 1996:77-78). In other words, a dyadic understanding of identity recognises the vital role of identity endorsement of in- and outgroups. Therefore, social role expectations and rules are essential to both identity construction and reception.

In PHLM, we identify at least two (even three) dominant groups and discourses that relate directly to the identity complexity of Onesimus; the overarching dominant Graeco-

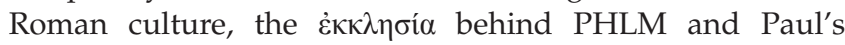
alternative insights challenging the Graeco-Roman discourse

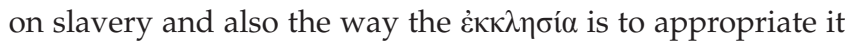
in a new way in this specific case of Onesimus. All these groups and discourses exercise influence on Onesimus' identity perception and thus must be taken into consideration when assessing how these identities interrelate and the complexity involved in navigating this kind of social identity complexity.

\section{Christ-kin: Impersonal to intimate relatedness}

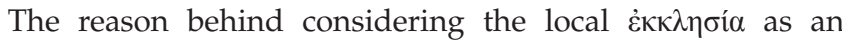
important ingroup at play behind PHLM has to do with the fact that PHLM is written to the $\dot{\varepsilon} \kappa \kappa \lambda \eta \sigma i \alpha$ gathering in the house of one of the addressees of PHLM. It is against the background of that Christ-following community that PHLM must be read and understood.

Through Paul's rhetoric we come to see how the whole Christ-following ingroup behind PHLM is challenged to

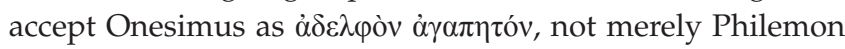
as an individual slave of someone else. An example of this rhetoric is found in verse 6, where Paul writes that through Philemon the whole fellowship of faith may learn what is

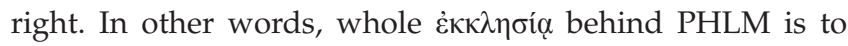


gain knowledge in what is good, which is obeying Paul's request to see Onesimus as their beloved brother.

However, in order for Onesimus to be welcomed within the $\dot{\varepsilon} \kappa \kappa \lambda \eta \sigma i ́ \alpha$ ingroup, they will have to see him as member of their kin, as a brother. Kinship language was often used amongst members of the ingroup as a way to express a close social relationship (Harland 2005:513). Therefore, accepting someone within an ingroup can only succeed when both parties recognise a sense of close relatedness or kinship between them. The rather distant impersonal dynamic between members of the in- and outgroup has to change to a sense of common personal connection (Malina 2001:63). Without the move from impersonal contact to interpersonal relationship, a person will remain an outsider for the ingroup. In other words, Onesimus' status as brother will remain wishful thinking if Paul does not achieve a change of Onesimus' identity perception in the ingroup. Furthermore, if Paul wants to secure that Onesimus indeed becomes a recognised member of the Christ-following ingroup behind PHLM, it is vital that a brotherly relationship between him and the ingroup is established. Therefore, because 'responsibility for morality and deviance is not on the individual alone but on the social body', Philemon's attitude towards Onesimus cannot remain an isolated change (Malina 2001:65). Instead, Philemon's behaviour ought to become the

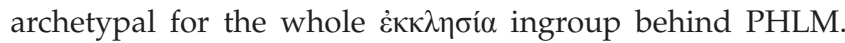

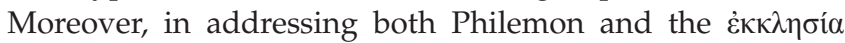
ingroup and persuading them to do what is good, Paul makes clear his expectations for the ingroup that Onesimus enters. Therefore, Philemon's behaviour towards Onesimus at his return will become representative for the whole $\dot{\varepsilon} \kappa \kappa \lambda \eta \sigma i ́ \alpha$ ingroup. From the perspective of social identity theory, one could argue that Paul as prototype wants Philemon to emulate his own prototypical behaviour and as such be an example to the rest of the community of faith to emulate them.

Because the sense of close relatedness is important to sustain strong ingroups and a necessary condition for acceptance within the ingroup, it is important that Philemon's behaviour is archetypal. If Philemon, who is bound by the expectations of the hierarchical relation between master and slave, can see his slave with the intimacy a brotherly relationship would require, the whole ingroup will be enabled to do the same.

Hence, through Paul's use of kinship language he has set the perimeters for how the Christ-following ingroup behind PHLM ought to function when confronted with Onesimus' return. Moreover, in using kinship language Paul constructs a dyadic understanding of self that the ancient communities could relate to. Reidar Aasgaard has argued that the social siblingship that Paul envisions in his letters is the glue that holds the Christ-following community together despite all its social diversity (see Aasgaard 2004:305-308). ${ }^{9}$ Therefore, kinship language partly functions to secure that outsiders, such as slaves, are allowed full membership of the Christ-kin (Bartchy 1999:69-75).

\section{Dyadic self and the dominant culture}

Nevertheless, Paul's vision of an inclusive Christ-kin would be a naïve fantasy without considering how this ingroup relates to the dominant culture in which it is embedded. Ingroups do not stand alone, neither does Paul isolate the Christ-following community from her broader cultural context. Moreover, one's dyadic self does not solely rely on the perception of the Christ-kin. In other words, someone's identity as a Christ-follower does not undo one's place in the dominant culture, nor the culture's impact on one's dyadic identity.

Within dyadic personality in a collectivist culture a person ought to behave in accordance with ingroup expectations, causing a discrepancy in Paul's constructing of Onesimus' identity. Paul wants Onesimus to be seen as a brother of both Philemon and by implication the Christ-following ingroup behind PHLM within the reality of a superordinate kinship family structure. However, Onesimus' other identity as a slave has repercussions for his place within the dominant host culture in which he still lives on daily basis. Not just Onesimus will be faced with these consequences, also Philemon's honourable position in society as pater familias will be at stake because he breaks the social values and status quo of his day in many ways.

Finally, even if the dominant Graeco-Roman culture would be regarded as (distant) outgroup, Malina (2001:66) reminded us that the soundness of the group, like behaviour of the collectivist personality individually, is heavily determined by its impact on surrounding groups and by the expectations of outsiders'. Thus, the Graeco-Roman dominant culture can still exert its influence in self-understanding as 'even in negative self-definition, the negated other(s) and their values continue to exercise a certain influence whether recognized or not' (Campbell 2008:64). Therefore, when asserting the dynamics between the multiple identities of Onesimus, we must look at the influence of the dominant culture on these identities.

To understand Onesimus' identity from the dominant cultural perspective we must consider the effect of ancient slavery to identity perception. Within NT scholarship the idea that slavery was characterised by oppression and dominion, both from a legal and sociological approach, is largely accepted in the guild. ${ }^{10}$ From the sociological perspective on slavery in the Graeco-Roman world, slavery is associated with disconnection. Other than their shameful place in the honour and shame society, slaves often lived without a sense of connectedness to a social group. A slave, by essence, would be characterised by a sense of separateness from familial, tribal and ethnical groups (Byron 2009:212-214). Glancy (2006:10-16) has even argued that slaves were not

10.Hunt (2018:18) points out that there were elite slaves in the Graeco-Roman world but this was highly exceptional and only reserved for extraordinarily wealthy people or noblemen. 
regarded as anything more than bodies that could be counted as property. Not just the slave's position in society would be amongst the least, also the lack of belonging meant that their sense of identity was non-existing to the surrounding culture. In this regard, Hunt (2018:20) writes that slaves 'lack all the rights that other people acquire by birth: their claims on their parents, their relations with siblings and their links with and prestige deriving from their ancestors'.

Therefore, what Paul aims to do, in the light of dyadic personality, is re-connecting Onesimus to a significant group, giving him a sense of identity, one that is recognised by his

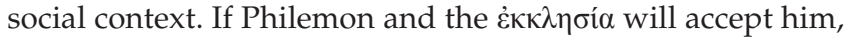
Onesimus is no longer merely associated with a lack of connection to the collective. However, in order for this reconnection to take place, his role as slave within the dominant culture as ultimately disconnected is untenable if both identities are to remain part of Onesimus. This highlights a few significant aspects of the nature of the possible conflict in Onesimus' identities, demonstrating the complexities at play in the social world behind PHLM. According to the most important value of its context, Philemon and Onesimus are to relate on superordinate level within a new Christfollowing kinship structure. But at the same time, they still remain master and slave on a subordinate level and have to function in a society in which such role expectations are still at work. The inherent tension between these two social identities causes a problem that cannot be overlooked. Sociorhetorical analysis has brought this tension to light, yet it does not offer an explanation as to how it is solved. Therefore, for the last part of this article we turn to SICT, which provides novel heuristic categories to describe the dynamics of how Paul's challenge to Philemon and Onesimus might be explained.

\section{'In Christ' dominance}

Based on the dyadic understanding of self, we may carefully conclude that Paul indeed envisioned an identity transformation in some regard for Onesimus. Because of his new identity as a brother he moves from complete disconnectedness as slave to a sense of connectedness. Moreover, Onesimus' new relatedness to the Christ-following kinship group shifts his identity perception from impersonal to interpersonal.

However, these insights do not yet answer the question to what extent the voices of these prominent groups behind PHLM (i.e. the Christ-following ingroup and the dominant culture) provide feedback to Onesimus' identity perception. Because, even if one argues that Paul wanted Onesimus to be manumitted (which is not our opinion), the egalitarian kinship language in PHLM goes against the grain of the Graeco-Roman cultural norms and expectations towards (former-) slaves, which would not have been called 'brothers' (see Hunt 2018:18). In both cases Paul's request invokes a social challenge through his provocative use of egalitarian terms to refer to a (former-) slave. Instead, Paul's main objective in PHLM is to see the relationship between
Onesimus and Philemon and by implication the whole $\dot{\varepsilon} \kappa \kappa \lambda \eta \sigma i \alpha$, transformed through Christ. A key verse to understand Paul's solution to Onesimus' identity complexity is verse 16 , where the two contrasting identities of slave and brother come together. In verse 16, Philemon no longer

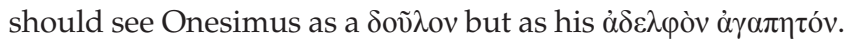

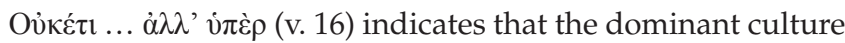
loses significant feedback for how Philemon perceives Onesimus' identity. The new Christ-following identity as 'beloved brother' determines a large part of his identity. McKnight (2017:95-99) also argues that although Onesimus' new identity in Christ may not have eradicated his status as slave, it implied a new way of thinking about identity in Christ and had implications for ancient social conceptions of identity of slave and master.

Therefore, although Onesimus is vi $x \rho$ a slave, it does not automatically mean that his slave identity has vanished altogether. In fact, $v \pi \varepsilon \rho$ as translated with 'more than' cannot lead to the conclusion that Onesimus is no longer a slave altogether. Instead, he is no longer $\dot{\omega} \varsigma$ a slave but 'more than' a slave. However, on the contrary, Paul does not propose that both identities provide identical feedback to Onesimus' identity either. Something is now superseding, i $\pi \dot{\varepsilon} \rho$, his identity as slave, namely his identity as a brother. For this reason, we may reject the model of intersection. For Paul does not suggest that the place of overlap between the two identities determines how they

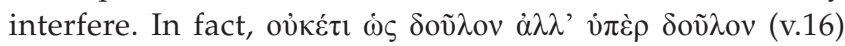
indicate that Onesimus' new identity transcends or supersedes his slave identity, without removing it. The

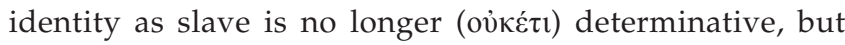
his identity as brother is pointing us in the direction of the model of dominance.

Another reason why the model of dominance may be considered as the strategy for Onesimus' identity complexity is found at the end of verse 16 . The manner in which Philemon

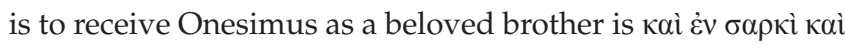

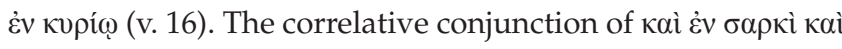

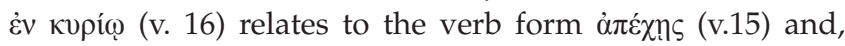
thus, must be read as the condition in which Philemon receives Onesimus. It is a further explanation of the spheres in which Philemon should receive Onesimus as a beloved brother.

Dunn (2014:336) has pointed out how Paul uses the terms है

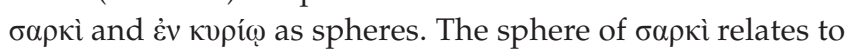
the earthly realm, and кupí relates to the spiritual or religious realm. So the new way Philemon ought to perceive Onesimus is twofold. Therefore, the sphere of $\dot{\varepsilon} v$ б $\alpha \kappa i ̀$ refers to the earthly dimension of their relationship as master and slave. On the contrary, the sphere of $\dot{\varepsilon} v \kappa v \rho i ́ \omega$ signifies their relationship as Christ-followers in which they relate as brothers. Although both spheres exist simultaneously, it is both within the earthly and the Christ-following reality that Onesimus is to be received as a beloved brother. The realms can, thus, also not be seen apart from each other. Philemon 


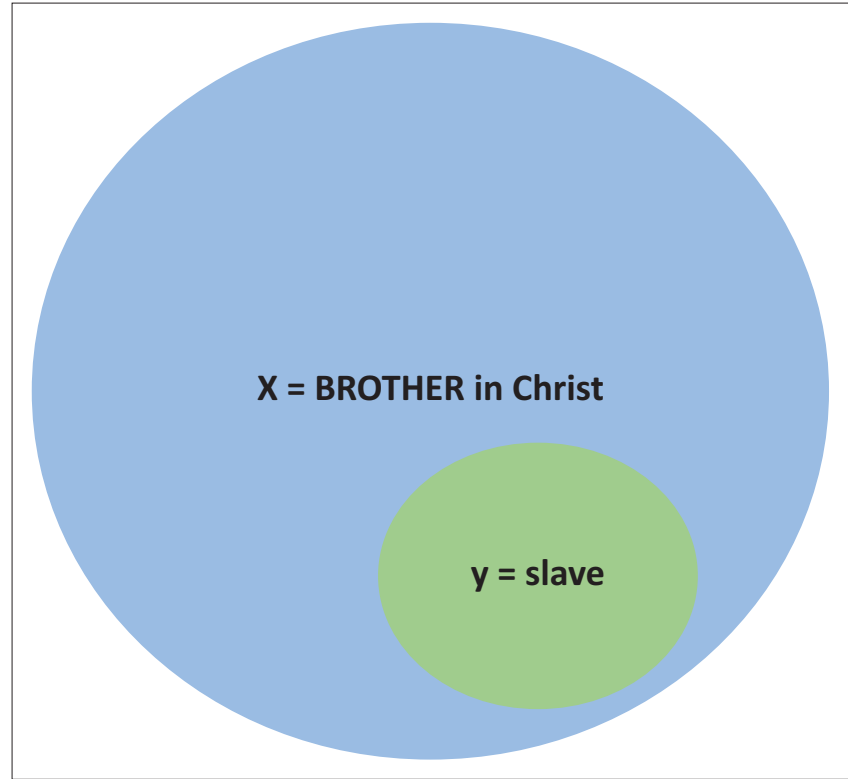

FIGURE 6: Dominance: Brother in Christ more dominant than slave.

cannot do what he wants in the secular domain and be his brother in the religious. Thus, Paul's challenge does not imply a form of compartmentalisation. Somehow the Christ-following identity leaves its traces in all areas of life. This argument thus points more into the direction of the model of dominance. It is not the sphere or setting of their relationship that determines whether Onesimus is seen as a slave or a brother, but in both spheres Onesimus is Philemon's brother. In other words, the Christ-following kinship is to be understood as dominant and infiltrating in all spheres. Or, as Heinsch puts it: 'Philemon's relationship to Onesimus, whether as his slave-owner or as his fellow co-worker, is always to be governed by their shared superordinate identity as brothers in Christ' (Heinsch 2020:483).

Consequently, Paul constructs Onesimus' new identity in such a manner that his earthly position as slave is informed by his identity as Christ-follower, so that he is considered a 'brother' in all areas of life.

\section{In Christ}

The notion that the Christ-following identity is superior to other identities is echoed in broader Pauline theology. Timothy Gombis, for example, notes that within the Christ-following community the ancient household codes were no longer the leading sources of identity feedback for Christ-followers. Instead, the Christ-following community became the new dominant social order. However, Gombis also argues that the new household in Christ does not eliminate the influence of the GraecoRoman household. ${ }^{11}$ Nevertheless, the love of Christ is to be dominant within the existing cultural structures. Thus, the membership of the Christ-following group becomes essential to experience this new social order. Its membership is, as it were, a requirement to enjoy its new household. Therefore, Paul's primary goal does not seem to enable a multitude of identities to express themselves simultaneously, as one would expect in the model of Merger. Instead, the Christ-following identity informs all other identities that may exist within a person. Although these identities may still be present, they are no longer informing how one is seen or treated within the Christfollowing group.

Consequently, one's social standing becomes less insignificant in the Christ-following group. As illustrated in Figure 6, we see how both identities keep existing, but one is dominant. In Onesimus' case, the dominant identity is his identity as brother as it determines how he is seen in all areas of life. The point of dominance is that the bigger circle is hierarchically more important or dominant than the smaller circle. Thus, my capacity as slave is less dominant than my capacity as brother.

Finally, as we have argued before, it is worth noting that because Philemon's response to Paul's request is to be

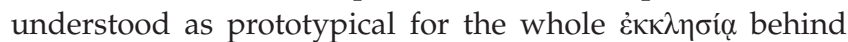

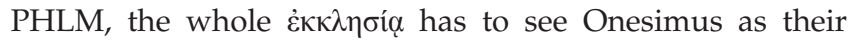
brother. Being a member of this ingroup means living in a community that radically transcends the social boundaries of its time. Thus, through this request, Paul constructs a community in which people from different social backgrounds are encouraged to show each other mutual respect and love as siblings would do. In Christ, a slave becomes his master's brother.

\section{Conclusion}

In this article, we have aimed to demonstrate how Paul solves the identity complexity arising as a slave enters into the Christ-following community of his master. Although the identity of Onesimus as slave (or at least inferior towards Philemon) remained, his new identity as Christfollower transformed the way his other identity was perceived. However, being 'in Christ' does not mean that slaves can still be treated as inferior. And through the strategy of dominance, the reality of a Christ-following slave within the context of his household is turned upside down.

However, we must be careful to conclude anything about the broader Pauline construction of the early Christfollowing social identity. More research in SICT is required to get insights into how the Christ-following community dealt with other conflicting identities. Nevertheless, we may also carefully conclude that the findings of SICT in PHLM does support previous claims by others concerning how Paul saw the Christ-following identity as a superordinate identity. This of course might have had significant implications for how the Early Christians not only saw each other within the community of faith, but also might have had a transformative effect on the world around them. 
The earliest Christians were in some ways countercultural in the manner in which their identity and ethos transcended boundaries. But they also illustrated a sense of sensitivity to outsiders, which attracted outsiders to the movement because of their radical ethos and identity and their unique kinship ties to one another (Campbell \& Campbell 2005: 82-85; Stark 1999).

\section{Acknowledgements}

This paper flows forth from Ilse Swart's unpublished Masters thesis at ETF Leuven under supervision of Prof. J. Kok.

\section{Competing interests}

The authors declare that they have no financial or personal relationships that may have inappropriately influenced them in writing this article.

\section{Authors' contributions}

J.K. was the supervisor who conceptualised the methodology and guided the master's thesis of I.S. who in collaboration with J.K. produced this research article.

\section{Ethical considerations}

This article followed all ethical standards for research without direct contact with human or animal subjects.

\section{Funding information}

This research received no specific grant from any funding agency in the public, commercial or not-for-profit sectors.

\section{Data availability}

Data sharing is not applicable to this article as no new data were created or analysed in this study.

\section{Disclaimer}

The views and opinions expressed in this article are those of the authors and do not necessarily reflect the official policy or position of any affiliated agency of the authors.

\section{References}

Aasgaard, R., 2004, My beloved brothers and sisters! Christian siblingship in Paul, T\&T Clark International, London

Bartchy, S., 1999, 'Undermining ancient patriarchy: The Apostle Paul's vision of a society of siblings', Biblical Theology Bulletin: Journal of Bible and Culture 29(2), 69-75. https://doi.org/10.1177/014610799902900203

Burke, T., 2003, Family matters: A socio-historical study of kinship metaphors in 1 Thessalonians, Bloomsbury T\&T Clark, London.

Byron, J., 2009, 'The epistle to Philemon: Paul's strategy for forging the ties of kinship' in B.J. Oropeza, C.K. Robertson \& D.C. Mohrmann (eds.), Jesus and Paul: Global Perspectives in Honor of James D.G. Dunn for His 70th Birthday, LNTS 414, pp. 207-216, T\&T Clark, London.
Campbell, J. \& Campbell, J., 2005, The way of Jesus: A journey of freedom for pilgrims and wanderers, 1st edn., Jossey-Bass, San Francisco, CA.

Campbell, W.S., 2008, Paul and the creation of Christian identity, T\&T Clark Biblical Studies, T\&T Clark, London.

Clarke, A.D. \& Tucker, J.B., 2014, 'Social history and social theory in the study of social identity', in J.B. Tucker \& C.A. Baker (eds.), T\&T Clark handbook to social identity in the New Testament, pp. 41-58, Bloomsbury Academic, London.

Darko, D.K., 2014, 'Adopted siblings in the household of God: Kinship lexemes in the social identity construction of Ephesians', in J.B. Tucker \& C.A. Baker (eds.), T\&T Clark handbook to social identity in the New Testament, pp. 333-346, Bloomsbury, London.

De Vos, C.S., 2001, 'Once a slave, always a slave? Slavery, manumission and relational patterns in Paul's letter to Philemon', Journal for the Study of the New Testament 23(82), 89-105. https://doi.org/10.1177/0142064X0102308204

Dunn, J.D.G., 2014, The epistles to the Colossians and to Philemon, Eerdmans, Grand Rapids, MI.

Glancy, J.A., 2006, Slavery in early Christianity, Fortress Press, Minneapolis, MN.

Gombis, T.G., 2010, Paul: A guide for the perplexed, Illustrated edn., T\&T Clark, London.

Harland, P.A., 2005, 'Familial dimensions of group identity: "Brothers" (A $\triangle \mathrm{E} \wedge \Phi \mathrm{OI})$ in Associations of the Greek East', Journal of Biblical Literature 124(3), 491-513. https://doi.org/10.2307/30041036

Haslam, A., 2004, Psychology in organizations: The social identity approach, 2nd edn., Sage, Thousand Oaks, CA.

Heinsch, R., 2020, 'Philemon', in B.J. Tucker \& A. Kuecker (eds.), T\&T Clark social identity commentary on the New Testament, pp. 476-486, Bloomsbury T\&T Clark, London.

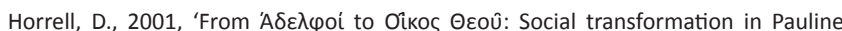
Christianity', Journal of Biblical Literature 120(2), 293-311. https://doi. org/10.2307/3268296

Hunt, L.J. 2020 '1 Peter', in B.J. Tucker \& A. Kuecker (eds.), T\&T Clark social identity commentary on the New Testament, pp. 527-542, Bloomsbury T\&T Clark, London.

Hunt, P., 2018, Ancient Greek and Roman Slavery, Wiley-Blackwell, Hoboken, NJ.

Kok, J., 2014, 'Social Identity Complexity Theory as heuristic tool in New Testament studies', HTS Teologiese Studies/Theological Studies 70(1), Art. \#2708, 9 pages. https://doi.org/10.4102/hts.v70i1.2708

Lim, K.Y., 2017, Metaphors and social identity formation in Paul's Letters to the Corinthians, Pickwick, Eugene, OR.

MacDonald, M., 2010, 'Kinship and family in the New Testament world', in D. Neufeld \& R.E. DeMaris (eds.), Understanding the social world of the New Testament, pp. 29-43, Routledge, London.

Malina, B., 2001, The New Testament world: Insights from cultural anthropology, 3rd edn., rev. expanded, Westminster John Knox, Louisville, KY.

Malina, B.J. \& Pilch, J.J., 2006, Social-science commentary on the Letters of Paul, Fortress Press, Minneapolis, MN.

McKnight, S., 2017, The letter to Philemon, Wm. B. Eerdmans Publishing, Grand Rapids, Ml.

Petersen, N., 2008, Rediscovering Paul: Philemon and the sociology of Paul's narrative world, Wipf \& Stock, Eugene, OR.

Pilch, J. \& Malina, B. (eds.), 2016, Handbook of biblical social values, 3rd edn., Matrix The Bible in Mediterranean Context 10, Cascade Books, Eugene, OR.

Robbins, V.K., 1996, Exploring the texture of texts: A guide to socio-rhetorical interpretation, Trinity Press International, Valley Forge, PA.

Roitto, R., 2008, '“Act as a Christ-believer, as a household member or as both? - A cognitive perspective on the relationship between the social identity in Christ and household identities in Pauline and Deutero-Pauline texts', in B. Holmberg \& M Winninge (eds.), Identity formation in the New Testament, ed. WUNT 227 pp. 141-162, Mohr Siebeck, Tübingen.

Roccas, S. \& Brewer, M.B., 2002, 'Social identity complexity', Personality and Social Psychology Review 6(2), 88-106. https://doi.org/10.1207/S15327 957PSPR0602_01

Stark, R., 1999, The rise of Christianity, Harper, San Francisco, CA.

Tucker, B., 2014, 'Paul's particular problem - The continuation of existing identities', in J.B. Tucker \& C.A. Baker (eds.), T\&T Clark handbook to social identity in the New Testament, pp. 407-424, Bloomsbury, London.

Tucker, B. \& Kuecker, A. (eds.), 2020, T\&T Clark Social Identity commentary on the New Testament, Bloomsbury T\&T Clark, London.

Tucker, J.B., 2010, You belong to Christ: Paul and the formation of social identity in 1 Corinthians 1-4, Pickwick Publications, Eugene, OR.

Tucker, J.B. \& Baker, C.A., (eds.), 2014, T\&T Clark handbook to social identity in the New Testament, Bloomsbury, London.

White, M.L., 2016, 'Paul and PaterFamilias', in J.P. Sampley (ed.), Paul in the GrecoRoman world: A handbook volume ii, pp. 171-203, Bloomsbury T\&T Clark, London.

Wright, N.T., 2008, Colossians and Philemon: An introduction and commentary, IVP Academic, Nottingham. 